\title{
Heregulin-1ß and HER3 in hepatocellular carcinoma: status and regulation by insulin
}

\author{
Corina Buta', Eva Benabou', Marie Lequoy ${ }^{1,2}$, Hélène Régnault ${ }^{1,3}$, Dominique Wendum ${ }^{1,4}$, Fatiha Merabtene ${ }^{1,5}$, \\ Hamza Chettouh', Lynda Aoudjehane ${ }^{1,6}$, Filomena Conti ${ }^{1,6,7}$, Yves Chrétien ${ }^{1}$, Olivier Scatton ${ }^{1,7}$, \\ Olivier Rosmorduc ${ }^{1,3}$, Françoise Praz ${ }^{1}$, Laetitia Fartoux ${ }^{1,3}$ and Christèle Desbois-Mouthon ${ }^{1^{*}}$
}

\begin{abstract}
Background: The heregulin-1ß/HER3-driven pathway is implicated in several epithelial malignancies and its blockade is currently undergoing clinical investigation. Paradoxically, the status and the regulation of this pathway is poorly known in hepatocellular carcinoma (HCC).

Methods: Using 85 HCC obtained after tumour resection, heregulin-1ß and HER3 expression was evaluated by real-time RT-PCR, ELISA and/or immunohistochemistry. Statistics were performed to analyze associations between gene expression and clinicopathological parameters. The effects of insulin on the heregulin-1ß/HER3 pathway was investigated in four HCC cell lines.

Results: HER3 mRNA was upregulated in $52 \%$ of tumours, while heregulin-1ß mRNA was downregulated in $82 \%$. Hepatitis B and C viral infections were respectively associated with high and low HER3 mRNA expression. No association was seen between neither HER3 or heregulin-1ß mRNA and prognostic factors, survival or recurrence. Immunohistochemistry showed predominant cytoplasmic staining of HER3 in tumours but the staining was nonreproducible. HER3 mRNA and protein levels were not correlated in liver tissues. In HCC cells, insulin promoted HER3 proteasomal degradation and inhibited heregulin-1ß stimulation of cell migration. HER3 and insulin receptor co-immunoprecipitated in these cells. The loss of insulin receptor expression by RNA interference sensitized cells to heregulin-1ß-induced AKT phosphorylation.

Conclusions: Autocrine heregulin-1ß loop is uncommon in HCC and HER3 mRNA expression is differentially influenced by hepatitis viruses. Insulin is a negative regulator of HER3 protein expression and function in HCC cells. Altogether these data may explain why HER3 and heregulin-1ß expression have no prognostic value and suggest that HCC patients are unlikely to derive benefit from HER3-targeted monotherapies.
\end{abstract}

Keywords: HER3/ERBB3, Insulin receptor, Hepatitis virus, Liver cancer

\section{Background}

Hepatocellular carcinoma (HCC) is a primary tumour of the liver whose incidence has steadily increased in recent years, reaching the fifth place worldwide. HCC has a dismal prognosis and it ranks second in terms of mortality. A minority of patients benefit from curative therapies (liver transplantation, tumour resection) and a high incidence of postoperative recurrence is observed after resection. Tumour recurrence is the major cause of

\footnotetext{
* Correspondence: christele.desbois-mouthon@inserm.fr

'Sorbonne Universités, UPMC Univ Paris 06, INSERM, Saint-Antoine Research

Center, 34 rue Crozatier, F-75012 Paris, France

Full list of author information is available at the end of the article
}

death following resection [1-3]. In this context, efforts must be pursued to better characterize HCC at genetic, molecular and cellular levels to identify key oncogenic pathways and therapeutical targets.

HER3 (ErbB3) belongs to the HER family including HER1 (ErbB1 or epidermal growth factor receptor (EGFR)), HER2 (ErbB2), and HER4 (ErbB4). Heregulin$1 ß$ (or neuregulin-1ß) is a high affinity ligand for HER3. HER3 has minimal tyrosine kinase activity and its full activation upon heregulin- $1 \beta$ binding, depends on its association with other HER members such as EGFR and HER2. Activated HER3 has six tyrosine-containing binding sites for the p85 regulatory subunit of PI3K in the 
cytoplasmic tail, making HER3 a major regulator of AKTdependent signalling [4-6]. These last years, the heregulin$1 ß /$ HER3 signalling axis has generated much interest in medical oncology. Indeed, high tumour expression of HER3 has been shown to be predictive of tumour progression and poor survival in patients with ovarian [7], breast $[8,9]$, melanoma [10] or gastric $[11,12]$ cancers. The presence of paracrine/autocrine heregulin-1ß loops also defines a subset of agressive tumours with higher recurrence in head and neck squamous cell carcinomas $[13,14]$. Yet, the poor prognostic value of HER3 and/or heregulin-1ß remains controversial in other cancers such as bladder cancer [15], uveal melanoma [16] and lung adenocarcinoma [17].

Data regarding the HER3 status in HCC are scarce. Available data have been essentially obtained from populations of Asian patients with viral hepatitis. A Japanese study reported that 64 out of $84 \mathrm{HCC}$ were positive for cytoplasmic HER3 by immunohistochemistry [18]. The transcriptomic profile of 37 hepatitis B virus (HBV)-related HCC showed that HER3 mRNA was one of the most frequently induced [19]. More recently, a Taiwanese group reported that upregulation of HER3 mRNA was associated with HBV etiology, microvascular invasion, early recurrence and poor clinical outcome in 71 patients with HCC [20]. No data are available regarding heregulin- $1 ß$ expression in HCC.

The present study was defined to gain information regarding the status of HER3 and heregulin-1ß in a French collection of HCC. We observed that HER3 mRNA expression was increased in $52 \%$ of 85 tumours while heregulin- $1 ß$ mRNA expression was reduced in $82 \%$. No prognostic value was found for HER3 or heregulin-1ß mRNA expression in this collection. In addition, no correlation was observed between HER3 mRNA and protein levels. The analysis of the posttranscriptional regulation of HER3 in HCC cell lines revealed that the heregulin-1ß/HER3 signalling pathway was controlled negatively by insulin at different levels.

\section{Methods}

\section{Patients and liver tissue specimens}

Eighty-five $\mathrm{HCC}(\mathrm{T})$ and paired adjacent non-tumour (NT) liver tissues were collected from patients undergoing curative liver resection for HCC at the Saint-Antoine hospital (Paris, France). Clinicopathological characteristics are summarized in Table 1. Part of this collection was used in our previous study where it was designated as collection \#2 [21]. All patients gave informed consent to the study, which was conducted in accordance with the French laws and regulations (CNIL n 1913901 v 0).

\section{Cell culture and treatments}

HepG2, Hep3B, and Huh7 cells were obtained from the American Type Culture Collection (ATCC). PLC/PRF5
Table 1 Clinicopathological characteristics of 85 patients with HCC

\begin{tabular}{|c|c|}
\hline \multicolumn{2}{|l|}{ Age at surgery (years) } \\
\hline Median [range] & $64.0[18-85]$ \\
\hline Sex ratio (M/F) & $5.1(71 / 14)$ \\
\hline \multicolumn{2}{|l|}{ Etiology of chronic liver disease, $n(\%)$} \\
\hline $\begin{array}{l}\text { HCV infection } \\
\text { HBV infection } \\
\text { Alcohol abuse } \\
\text { Hemochromatosis } \\
\text { NASH } \\
\text { Combined viral hepatitis and alcohol } \\
\text { Combined metabolic syndrome and alcohol } \\
\text { Undetermined }\end{array}$ & $\begin{array}{l}21(24.7) \\
27(31.8) \\
5(5.9) \\
2(2.3) \\
11(12.9) \\
5(5.9) \\
8(9.4) \\
11(12.9)\end{array}$ \\
\hline Advanced fibrosis/cirrhosis, $n$ (\%) & $49(57.6)$ \\
\hline Maximal tumour size, mean \pm SD $(\mathrm{mm})$ & $65.2 \pm 38.5$ \\
\hline $\operatorname{AFP}(\geq 400 \mathrm{ng} / \mathrm{ml}), n(\%)^{\mathrm{a}}$ & $15(17.6)$ \\
\hline Multiplicity, n (\%) & $18(21.2)$ \\
\hline \multicolumn{2}{|l|}{ Tumour grade } \\
\hline $\begin{array}{l}\text { Well differentiated, } n \text { (\%) } \\
\text { Moderately differentiated, } n \text { (\%) } \\
\text { Poorly differentiated, } n(\%)\end{array}$ & $\begin{array}{l}21(24.7) \\
41(48.2) \\
23(27.0)\end{array}$ \\
\hline CK19 expression, $n(\%)^{b}$ & $17(20.0)$ \\
\hline Microvascular invasion, $n(\%)$ & $40(47.0)$ \\
\hline Satellite nodules, $n(\%)$ & $26(30.5)$ \\
\hline Recurrence, $n(\%)$ & $45(52.9)$ \\
\hline Recurrence before 2 years, $n(\%)$ & $40(47.1)$ \\
\hline Delay to recurrence (months), median [range] & $7.8[1-61]$ \\
\hline Overall mortality, n (\%) & $29(34.1)$ \\
\hline
\end{tabular}

AFP a-fetoprotein, CK19 cytokeratin 19, HCV hepatitis C virus $H B V$ hepatitis B virus, NASH non alcoholic steatohepatitis

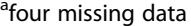

${ }^{b}$ three missing data

cells were provided by $\mathrm{Dr}$ Christine Perret (Institut Cochin, France). Cell line authentication was routinely performed by using a panel of nine ATCC short tandem repeats. Cell lines were cultured as previously reported [22] and routinely controlled for mycoplasma contamination. Primary cultures of human hepatocytes were established as previously described [23]. In some experiments, serum-deprived cells were treated with insulin, IGF-II (Sigma-Aldrich), heregulin-1ß (R\&D Systems), cycloheximide, bafilomycin A1 (Sigma-Aldrich) and/or MG-132 (Cell Signaling Technology).

\section{Western blotting and ELISA}

Protein electrophoresis and transfert to nitrocellulose were performed according to standard procedures. The primary antibodies are summarized in Additional file 1: Table S1. Blot revelations and quantifications were performed using ChemiDoc $^{\text {tm }}$ Touch Imaging System (BIORAD). Total amounts of HER3 and heregulin-1 $\beta$ were quantified in human liver tissue extracts by ELISA according to manufacturer's instructions (R\&D Systems). 


\section{RNA interference}

The expression of specific mRNA was downregulated using a mixture of four siRNAs $(100 \mathrm{nmol} / \mathrm{L}, \mathrm{ON}-$ TARGETplus SMARTpool, Dharmacon) and Dharmafect 4 (Dharmacon). Controls were performed using a nontargeting siRNA pool (Dharmacon).

\section{RNA isolation and analysis of gene expression}

Total RNA was extracted from cell cultures using RNeasy Mini kit (Qiagen). For liver tissues, a preliminary RNA extraction step was performed using TRIzol Reagent (Life Technologies). Quantitative measurements of transcripts were performed by real-time PCR on a LightCycler 480 instrument (Roche) using SYBR Green chemistry and specific primers (Additional file 1: Table S2). For each sample, gene expression was normalized to that of hypoxanthine guanine phosphoribosyltransferase mRNA content and was expressed relatively to the same calibrator. The relative quantity of each target gene was determined from replicate samples using the formula $2^{-\Delta \Delta \mathrm{Ct}}$.

\section{Immunohistochemistry}

Paraffin-embedded 4- $\mu \mathrm{m}$ sections were dewaxed in xylene and rehydrated in graded alcohol series and microwave antigen retrieval was performed in $10 \mathrm{mM}$ citrate buffer $\mathrm{pH} 6$ during 15 min. Primary antibody detection was performed using Novolink Polymer Detection System (Novocastra, Leica Biosystems) according to the manufacturer's protocol on an automated staining system (Dakocytomation ${ }^{\circ}$ ). Aminoethyl carbazole was used to reveal the peroxidase activity. The sections were counterstained with haematoxylin. Four different HER3 monoclonal antibodies were tested (Additional file 1: Table S1) but only the clone RTJ1 (Thermo Scientific, 1:30 dilution, overnight at $4{ }^{\circ} \mathrm{C}$ ) gave signals. The clone RTJ1 was validated by siRNA-mediated knockdown and Western blotting (Additional file 2: Figure S1).

\section{Immunofluorescence analysis}

Cells seeded on glass coverslips were fixed with $4 \%$ paraformaldehyde, blocked with $1 \%$ BSA and $10 \%$ goat serum in PBS, followed by overnight incubation with a 1:250 dilution of the primary antibody in PBS at $4{ }^{\circ} \mathrm{C}$ (Additional file 1: Table S1). Cells were then incubated with a 1:200 dilution of conjugated secondary antibody (Alexa Fluor ${ }^{\circ}$ 488 or 546 dye) in PBS for $1 \mathrm{~h}$ at room temperature. The slides were counterstained with 4',6-diamidino-2-phenylindole (DAPI) for nuclei detection. Fluorescence was visualized using an immunofluorescence microscope (Leica Microsystems) with a DFC300 FX digital camera.

\section{Cell migration assays}

Migration was performed in $6.5 \mathrm{~mm}$ Transwell $^{\circ}$ with $8-\mu \mathrm{m}$ pore polycarbonate membrane insert (Corning). Cells $\left(1 \times 10^{5}\right)$ in medium without serum were plated in the upper chamber and medium containing $10 \%$ fetal bovine serum (FBS) was added in the lower chamber as a chemoattractant. After $24 \mathrm{~h}$, cells were treated with or without insulin or heregulin-1 $\beta$ for $24 \mathrm{~h}$. Cells that had not migrated were removed from the upper surface of inserts by using cotton-tipped swabs and migrated cells that were attached to the lower surface were enumerated by microscopy following fixation by $4 \%$ paraformaldehyde for $15 \mathrm{~min}$ and nucleic acid staining with DAPI. Four random fields were counted per insert. For the woundhealing assay, cells $\left(5 \times 10^{4}\right)$ were seeded in a 24-well dish, incubated for $24 \mathrm{~h}$ in complete medium and serumharvested overnight. The cell monolayers were pretreated with mitomycin $C(1 \mu \mathrm{g} / \mathrm{ml})$ for $2 \mathrm{~h}$ to inhibit cell proliferation, scraped with a p200 pipet tip and washed. Cells were then treated with or without insulin or heregulin-1 $\beta$. Photographs were taken at 0 and $48 \mathrm{~h}$ with a phasecontrast microscope and at least ten fields were recorded for each treatment.

\section{Statistical analysis}

Comparison of mRNA expression between tumours and adjacent liver tissue was performed using Wilcoxon signedrank test. The association between gene expression (T/NT ratio) and clinicopathological features was evaluated using the Mann-Whitney U-test. Survival analysis was done by the Kaplan-Meier method and the groups were compared with the log-rank test. Data from in vitro experiments were reported as means +/- SEM of at least three independent experiments. The comparisons of different groups were carried out using Mann-Whitney test. Differences were considered statistically significant at $p<0.05$.

\section{Results}

HER3 and heregulin-1ß mRNA expression is not associated with clinicopathological markers of tumour progression and reduced survival in HCC

We analysed the expression of HER3 mRNA in a French collection of 85 resected HCC. We observed that HER3 mRNA was increased in $52 \%$ of HCC $(\mathrm{T})$ versus paired non-tumour (NT) liver tissue with a median fold-induction of 1.94 (Fig. 1a). High HER3 T/NT ratios were associated with $\mathrm{HBV}$, while lower values were associated with $\mathrm{HCV}$ (Table 2). Except for tumour size, the HER3 T/NT ratio was not associated with histological and biological markers reminiscent of tumours with poor outcome such as CK19 expression, satellite nodules, multiplicity, microvascular invasion and high serum levels of AFP (Table 2). The HER3 $\mathrm{T} / \mathrm{NT}$ ratio was higher in well/moderately differentiated tumours than in poorly differentiated tumours. Finally, there was no difference in overall survival (OS) or recurrencefree survival (RFS) in patients with high or low HER3 T/NT ratio (Fig. 1b). 

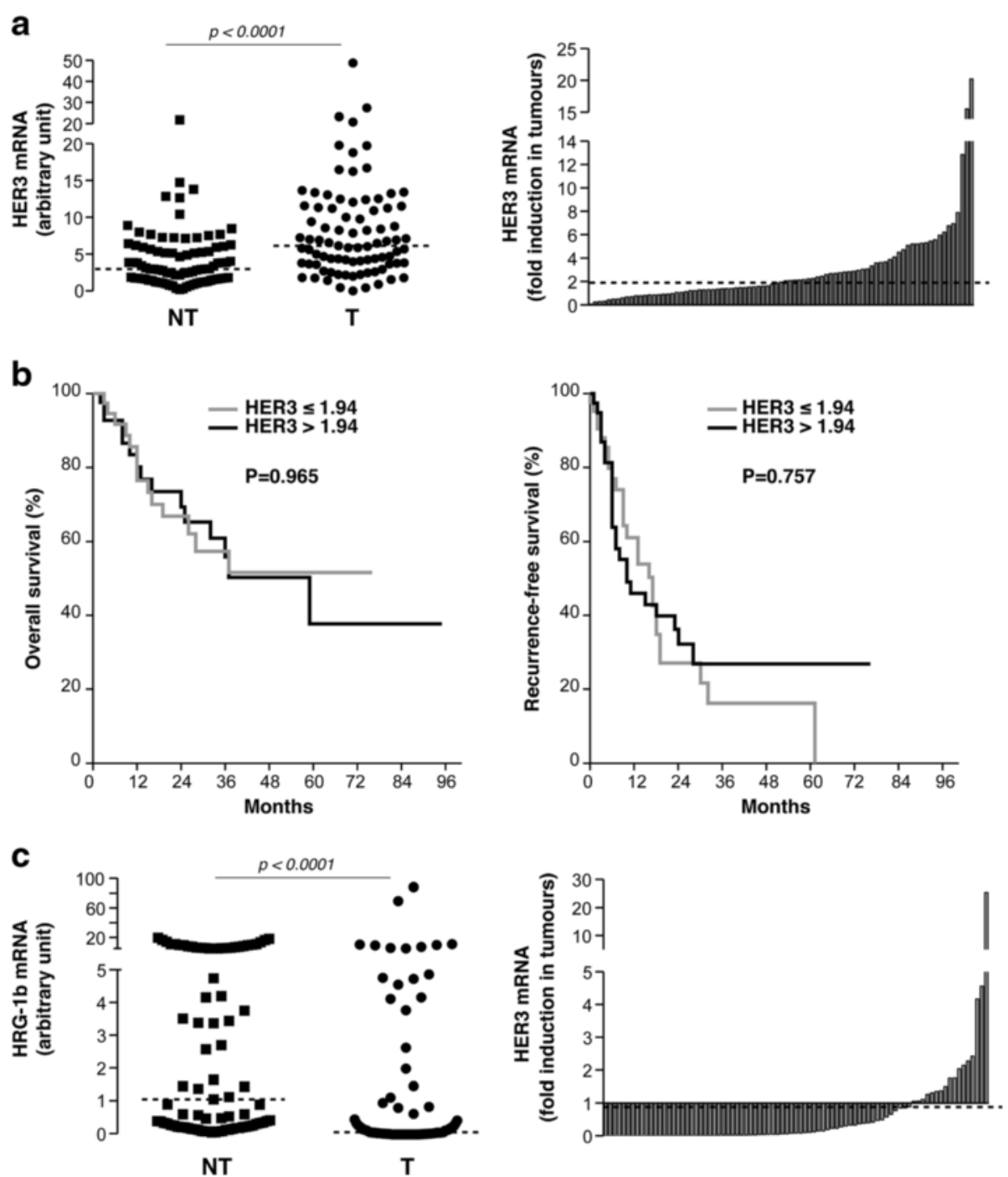

Fig. 1 HER3 and heregulin-1ß mRNA expression in HCC. a HER3 mRNA expression was evaluated by RT-qPCR in 85 human paired T/NT liver tissue samples (left). The distribution of HER3 T/NT ratio is presented on the right side. $\mathbf{b}$ Kaplan-Meier analysis of the probabilities of overall survival (left) and recurrence-free survival (right) according to the upregulation of HER3 mRNA. c Heregulin-1ß mRNA expression was evaluated by RT-qPCR in 85 human paired T/NT liver tissue samples (left). The distribution of heregulin-1ß T/NT ratio is presented on the right side

Similar analyses were conducted for heregulin-1ß ligand. Heregulin-1ß mRNA levels were lower in $82 \%$ of HCC compared with surrounding liver tissue (median fold-ratio of 0.09) (Fig. 1c). The heregulin-1ß expression ratio $(\mathrm{T} / \mathrm{NT})$ correlated neither with tumour size, multiplicity, microvascular invasion, OS nor RFS (Table 2 and Additional file 3: Figure S2); it was higher in CK19-negative and well/moderately differentiated tumours.

HER3 mRNA and protein levels are not correlated in HCC and adjacent liver tissue

We then attempted to investigate HER3 protein expression by immunohistochemistry. Out of four primary antibodies tested, only the RTJ1 clone yielded staining. This staining was exclusively cytoplasmic. This finding raises questions regarding the validity of these signals since HER3 is supposed to be also localized at cell membrane. Moreover, HER3 staining turned out to be nonreproducible in terms of intensity as illustrated in Fig. 2a and no reliable association studies could be performed from these analyses.

Thirty-two paired T/NT tissue samples previously analysed for HER3 mRNA expression were also measured for HER3 protein levels by ELISA. We observed no statistical difference between HER3 protein contents in tumours vs nontumour liver tissues (Fig. 2b, left). Spearman correlation analysis indicated no correlation between HER3 mRNA 
Table 2 Relations between HER3 and heregulin-1ß mRNA fold inductions (T/NT) and the pathological characteristics of 85 HCC

\begin{tabular}{|c|c|c|c|c|c|}
\hline & Number & HER3 mRNA fold induction (T/NT) ${ }^{a}$ & $P$ values & Heregulin-1ß fold induction (T/NT) $)^{a}$ & $P$ values \\
\hline \multicolumn{6}{|l|}{ HBV } \\
\hline $\begin{array}{l}\text { Yes } \\
\text { No }\end{array}$ & $\begin{array}{l}27 \\
58\end{array}$ & $\begin{array}{l}2.38[0.29-20.25] \\
1.55[0.07-15.51]\end{array}$ & 0.033 & $\begin{array}{l}0.02[0.00-4.56] \\
0.13[0.00-25.46]\end{array}$ & 0.075 \\
\hline \multicolumn{6}{|l|}{ HCV } \\
\hline $\begin{array}{l}\text { Yes } \\
\text { No }\end{array}$ & $\begin{array}{l}21 \\
64\end{array}$ & $\begin{array}{l}1.30[0.25-12.86] \\
2.21[0.07-20.25]\end{array}$ & 0.016 & $\begin{array}{l}0.06[0.00-4.17] \\
0.095[0.00-25.46]\end{array}$ & 0.724 \\
\hline \multicolumn{6}{|l|}{$\mathrm{NASH}$} \\
\hline $\begin{array}{l}\text { Yes } \\
\text { No }\end{array}$ & $\begin{array}{l}11 \\
74\end{array}$ & $\begin{array}{l}2.74[0.69-5.30] \\
1.60[0.07-20.25]\end{array}$ & 0.313 & $\begin{array}{l}0.33[0.02-2.04] \\
0.05[0.00-25.46]\end{array}$ & 0.074 \\
\hline \multicolumn{6}{|l|}{ MS + alcohol } \\
\hline $\begin{array}{l}\text { Yes } \\
\text { No }\end{array}$ & $\begin{array}{l}8 \\
77\end{array}$ & $\begin{array}{l}1.32[0.85-4.50] \\
2.06[0.07-20.25]\end{array}$ & 0.425 & $\begin{array}{l}0.715[0.05-25.46] \\
0.06[0.00-4.56]\end{array}$ & 0.011 \\
\hline \multicolumn{6}{|l|}{ Alcohol } \\
\hline $\begin{array}{l}\text { Yes } \\
\text { No }\end{array}$ & $\begin{array}{l}5 \\
80\end{array}$ & $\begin{array}{l}2.11[0.96-6.77] \\
1.85[0.07-20.25]\end{array}$ & 0.727 & $\begin{array}{l}0.10[0.00-0.89] \\
0.08[0.00-25.46]\end{array}$ & 0.783 \\
\hline \multicolumn{6}{|c|}{ Advanced fibrosis/cirrhosis } \\
\hline $\begin{array}{l}\text { Yes } \\
\text { No }\end{array}$ & $\begin{array}{l}50 \\
35\end{array}$ & $\begin{array}{l}1.52[0.25-20.25] \\
2.60[0.07-15.51]\end{array}$ & 0.150 & $\begin{array}{l}0.090[0.00-4.17] \\
0.090[0.00-25.46]\end{array}$ & 0.719 \\
\hline \multicolumn{6}{|l|}{$\mathrm{AFP}^{\mathrm{b}}$} \\
\hline $\begin{array}{l}<400 \mathrm{ng} / \mathrm{ml} \\
\geq 400 \mathrm{ng} / \mathrm{ml}\end{array}$ & $\begin{array}{l}47 \\
34\end{array}$ & $\begin{array}{l}1.85[0.07-20.25] \\
2.09[0.25-15.51]\end{array}$ & 0.867 & $\begin{array}{l}0.13[0.00-4.56] \\
0.05[0.00-25.46]\end{array}$ & 0.293 \\
\hline \multicolumn{6}{|l|}{ Tumour size } \\
\hline $\begin{array}{l}<5 \mathrm{~cm} \\
\geq 5 \mathrm{~cm}\end{array}$ & $\begin{array}{l}44 \\
41\end{array}$ & $\begin{array}{l}1.47[0.25-7.89] \\
2.68[0.07-20.25]\end{array}$ & 0.019 & $\begin{array}{l}0.09[0.00-4.56] \\
0.09[0.00-25.46]\end{array}$ & 0.631 \\
\hline \multicolumn{6}{|l|}{ Multiplicity } \\
\hline $\begin{array}{l}\text { Yes } \\
\text { No }\end{array}$ & $\begin{array}{l}18 \\
67\end{array}$ & $\begin{array}{l}2.05[0.32-20.25] \\
1.94[0.07-7.89]\end{array}$ & 0.796 & $\begin{array}{l}0.24[0.00-4.17] \\
0.06[0.00-25.46]\end{array}$ & 0.310 \\
\hline \multicolumn{6}{|l|}{ Satellite nodules } \\
\hline $\begin{array}{l}\text { Yes } \\
\text { No }\end{array}$ & $\begin{array}{l}26 \\
59\end{array}$ & $\begin{array}{l}2.11[0.07-20.25] \\
1.58[0.25-7.89]\end{array}$ & 0.458 & $\begin{array}{l}0.15[0.00-25.46] \\
0.05[0.00-4.56]\end{array}$ & 0.164 \\
\hline \multicolumn{6}{|l|}{ Differentiation } \\
\hline $\begin{array}{l}\text { Well/moderate } \\
\text { Poor }\end{array}$ & $\begin{array}{l}61 \\
24\end{array}$ & $\begin{array}{l}2.22[0.29-20.25] \\
1.43[0.07-6.77]\end{array}$ & 0.021 & $\begin{array}{l}0.23[0.00-25.46] \\
0.01[0.00-1.76]\end{array}$ & 0.001 \\
\hline \multicolumn{6}{|l|}{ CK19 expression ${ }^{c}$} \\
\hline $\begin{array}{l}<5 \% \\
\geq 5 \%\end{array}$ & $\begin{array}{l}65 \\
17\end{array}$ & $\begin{array}{l}1.85[0.25-20.25] \\
2.44[0.07-15.51]\end{array}$ & 0.926 & $\begin{array}{l}0.11[0.00-25.46] \\
0.01[0.00-1.06]\end{array}$ & 0.006 \\
\hline \multicolumn{6}{|c|}{ Microvascular invasion } \\
\hline $\begin{array}{l}\text { Yes } \\
\text { No }\end{array}$ & $\begin{array}{l}41 \\
44\end{array}$ & $\begin{array}{l}2.08[0.07-20.25] \\
1.56[0.29-6.94]\end{array}$ & 0.194 & $\begin{array}{l}0.08[0.00-25.46] \\
0.09[0.00-4.56]\end{array}$ & 0.624 \\
\hline
\end{tabular}

AFP a-fetoprotein, CK19 cytokeratin 19, HCV hepatitis C virus

$H B V$ hepatitis $B$ virus, $M S$ metabolic syndrome, NASH non alcoholic steatohepatitis

${ }^{a}$ Values are expressed as median [range]

${ }^{\mathrm{b}}$ four missing data

three missing data

All statistical analyses were performed using Mann-Whitney test

levels (evaluated by real-time PCR) and HER3 protein levels (evaluated by ELISA) (Spearman $r=-0.230 ; p=0.071$; Fig. $2 b$, right). In contrast, heregulin- $1 ß$ protein levels were decreased in tumours compared with nontumour liver tissues (Fig. 2c, left) and heregulin-1ß mRNA and protein levels tended to be positively correlated (Spearman $r=0.289 ; p=0.023$; Fig. 2c, right). The lack of correlation between HER3 transcript and protein levels suggested that HER3 is subjected to post-transcriptional and/ or post-translational regulation in human liver samples. 
a
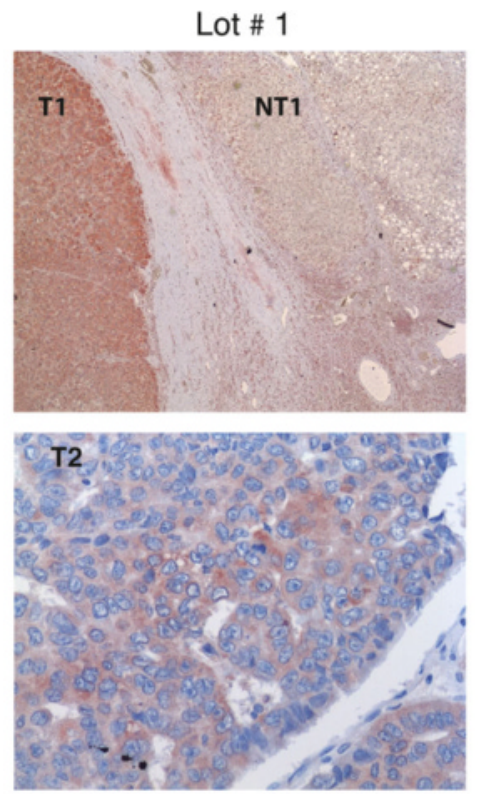

b

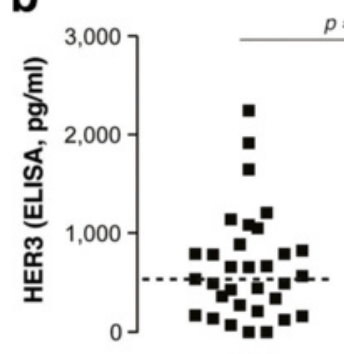

NT

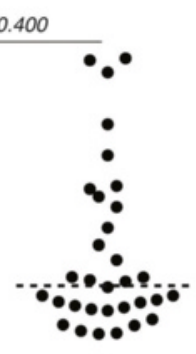

$\mathrm{T}$

C

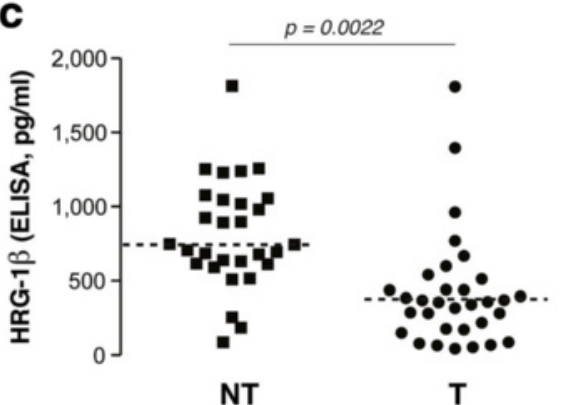

Lot \# 2
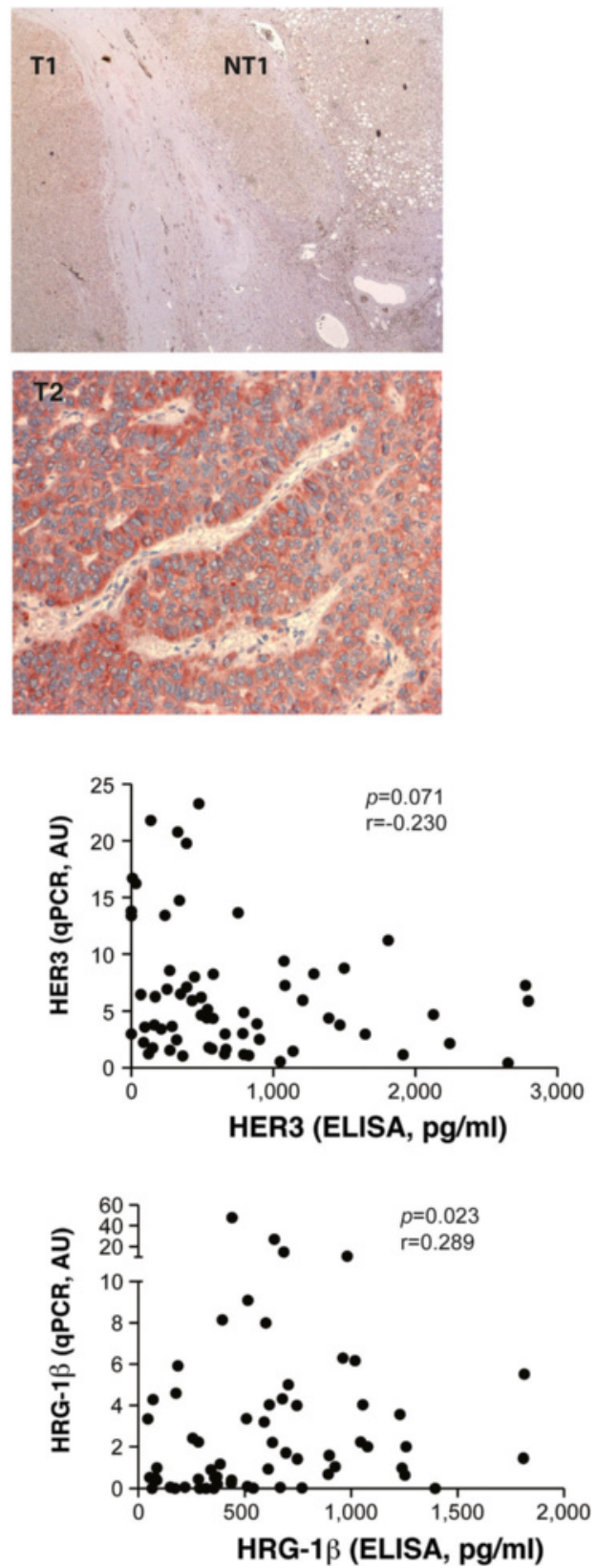

Fig. 2 HER3 protein expression in HCC. a HER3 detection by immunohistochemistry with RTJ1 antibody revealed cytoplasmic staining in HCC. Representative pictures of two tumours $(\mathrm{T} 1, \mathrm{~T} 2)$ are shown. HER3 staining was non reproducible in terms of intensity between two lots of antibody (compare left and right panels). b left, HER3 protein expression evaluated by ELISA in 32 paired T/NT liver tissue samples; right, correlations between HER3 mRNA and protein levels. c left, heregulin-1ß (HRG-1ß) protein expression evaluated by ELISA in 32 paired T/NT liver tissue samples; right, correlations between heregulin-1ß mRNA and protein levels

Insulin promotes HER3 degradation in human hepatocytes and HCC cell lines

Limited data are available regarding the post-transcriptional and post-translational mechanisms controlling HER3 expression in hepatocytes. A few years ago, Carver and colleagues reported that in cultured rat hepatocytes insulin impaired heregulin-1ß signalling by promoting HER3 downregulation [24]. We examined whether such a mechanism was relevant to human normal and transformed hepatocytes, that expressed both HER3 and IR receptors $[21,22]$. As shown in Fig. 3a, insulin down-regulated HER3 protein expression in primary cultures of normal human hepatocytes. A similar effect was observed in the presence of IGF-II, another ligand to the insulin receptor 
a

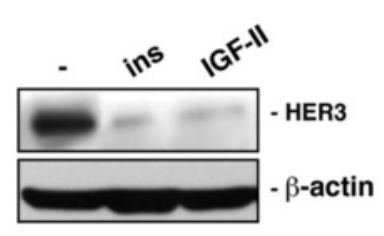

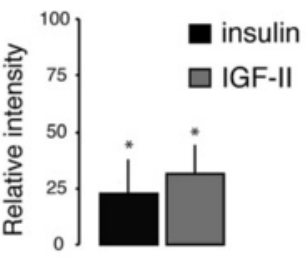

b

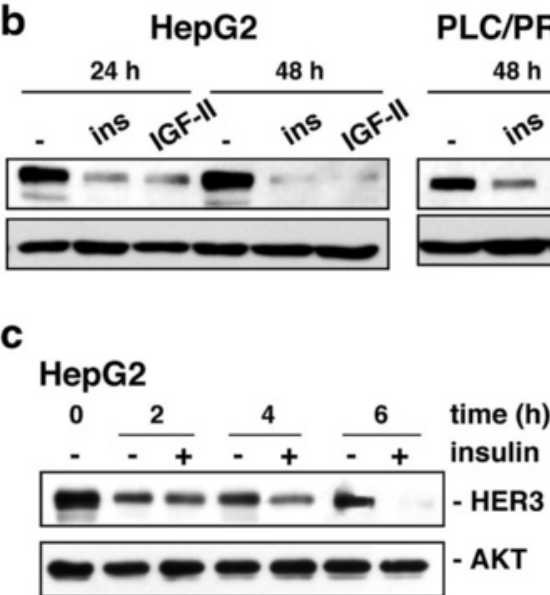

\section{PLC/PRF5}

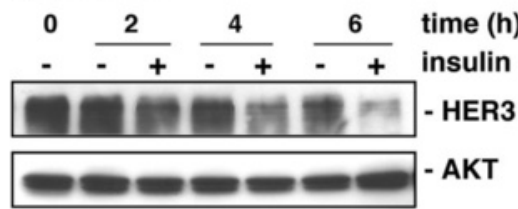

\section{d}

\section{HepG2}

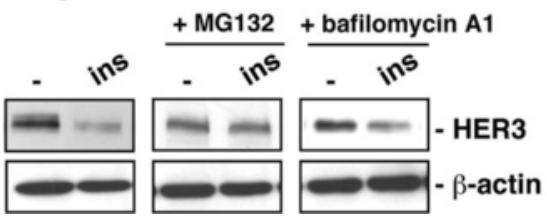

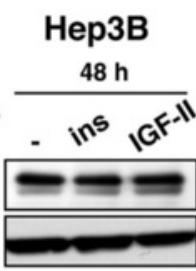
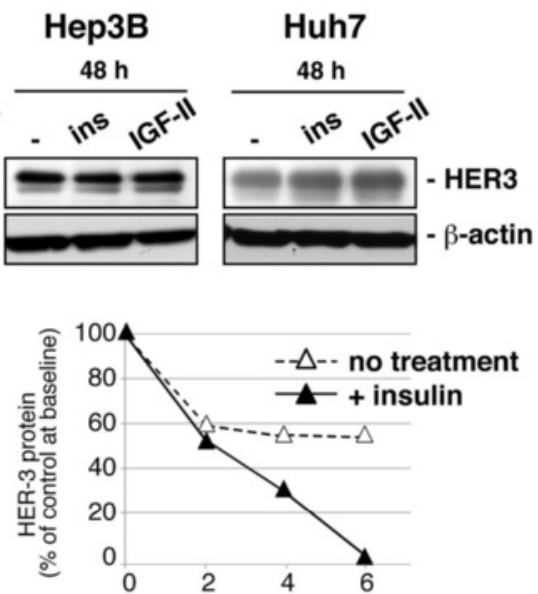

Treatment with $\mathrm{CHX}$ (h)

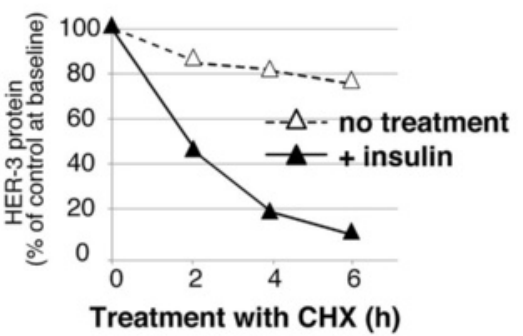

PLC/PRF5

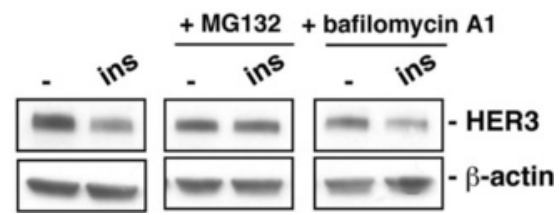

Fig. 3 Effects of insulin on HER3 protein in normal hepatocytes and HCC cell lines. a-b Human normal hepatocytes and liver cancer cell lines (HepG2, PLC/PRF5, Hep3B, Huh7) were treated with $10^{-8} \mathrm{M}$ insulin (ins) or IGF-II for 24 and $48 \mathrm{~h}$. Whole-cell lysates (20 ug) were analysed by Western blot for HER3 expression. B-actin detection was performed to control protein loading. c Serum-starved HepG2 and PLC/PRF5 cells were treated for $24 \mathrm{~h}$ with or without $10^{-8} \mathrm{M}$ insulin, then with cycloheximide $(\mathrm{CHX}, 40 \mathrm{ng} / \mathrm{ml})$ for different durations, analyzed by Western blot for HER3 expression and quantified. AKT detection was performed to control protein loading. $\mathbf{d}$ Serum-starved HepG2 and PLC/PRF5 cells were treated for $24 \mathrm{~h}$ with or without $10^{-8} \mathrm{M}$ insulin, $10 \mathrm{uM} \mathrm{MG132}$, or $100 \mathrm{nM}$ bafilomycin and analyzed by Western blot for HER3 expression. B-actin detection was performed to control protein loading. Blots are representative of three independent experiments

(IR). Insulin and IGF-II also decreased HER3 protein levels in HepG2 and PLC/PRF5 cancer cells but not in Hep3B and Huh7 cells (Fig. 3b). There was no decrease in HER3 mRNA levels after insulin treatment in HepG2 and PLC/PRF5 cells (Additional file 4: Figure S3A), showing that the effect of insulin was posttranscriptional. To determine whether the decreased levels of
HER3 in insulin-stimulated HCC cells were due to increased degradation, we blocked the de novo protein synthesis with cycloheximide and analyzed the rates of HER3 decay. The half-life of HER3 in insulinstimulated cells was shorter $(2-3 \mathrm{~h})$ than in unstimulated cells $(>6 \mathrm{~h})$ (Fig. 3c) indicating that insulin destabilizes HER3 protein. We then examined how insulin promoted 
HER3 degradation. First, we observed that treatment of HepG2 and PLC/PRF5 cells with the specific proteasome inhibitor MG132 for $24 \mathrm{~h}$ reversed the effect of insulin on HER3 downregulation while bafilomycin A, a selective inhibitor of lysosomal v-ATPase, was ineffective (Fig. 3d). This indicated that the negative regulation of HER3 protein levels by insulin was a proteasome-mediated process. Additionally, it seemed that the effect of insulin did not require the involvement of NRDP1, an E3 ubiquitin ligase, which can control the steady-state levels of HER3 [25]. Indeed, insulin did not modify NRDP1 expression and more importantly siRNA-induced downregulation of NRDP1 expression did not impact insulin effect on HER3 expression (Additional file 4: Figure S3 B and C).

\section{Insulin inhibits heregulin-1ß stimulation of migration in HCC cell lines}

We then examined whether insulin impacted heregulin-1ß/ HER3-dependent biological effects in Hep3B and Huh7 cell lines in which the hormone did not down-regulate HER3 expression. As shown in Fig. 4a, heregulin-1ß promoted cell migration as evaluated by Transwell migration assays in these cell lines while it was ineffective to stimulate proliferation and viability (Additional file 5: Figure S4). Insulin was a potent mitogen in these cell lines [21] but had no effect on cell migration (Fig. 4a). When insulin was combined to heregulin- $1 \beta$, we observed that the promigratory effect of heregulin-1ß was reduced in Hep3B and Huh7 cell lines (Fig. 4a). The ability of insulin to counteract heregulin-1ß migratory effect was confirmed in Huh7 cells using a wound healing assay (Fig. 4b).

\section{HER3 is associated to IR in HCC cell lines}

As a first step to investigate the mechanisms underlying the functional interaction between heregulin-1ß- and insulin-dependent pathways, we examined the cellular localization of HER3 and IR by immunofluorescence (Fig. 5a). In HCC cell lines, the two receptors showed a partially overlapping pattern of distribution. A potential interaction between IR and HER3 in HCC cells was next assessed by immunoprecipitation. HER3 was immunoprecipitated from whole-cell lysates, and the resulting precipitates were subjected to immunoblot analysis with an antibody to IR. In all cell lines, we observed that HER3 coimmunoprecipitated with IR (Fig. 5b).

\section{Insulin inhibits the heregulin-1ß/HER3/AKT pathway in HCC cell lines}

We then examined the impact of insulin on the heregulin$1 ß /$ HER3 signalling axis in HCC cells. The effect of insulin on HER3 phosphorylation was evaluated by Western blot by analysing two major tyrosine phosphorylation sites, Y1289 and Y1197. Strikingly, the hormone induced an increase of HER3 Y1289 phosphorylation in Hep3B cells while it was ineffective to promote HER3 Y1197 phosphorylation (Fig. 6a, left). As a comparison, both tyrosine residues were potently phosphorylated by heregulin- $1 ß$ (Fig. 6a, right). Insulin-induced phosphorylation of HER3 Y1289 was reduced when IR expression was downregulated with siRNA (Fig. 6b). The stimulatory effect of insulin on HER3 Y1289 phosphorylation was observed in the three other cell lines but to a lesser extent (Additional file 6: Figure S5). As insulin also promoted EGFR phosphorylation in HCC cells (Fig. 6c), we wondered whether insulin induction of Y1289 HER3 phosphorylation required EGFR activity. The effect of insulin on HER3 was maintained in the presence of gefitinib, an EGFR TKI, or after EGFR downregulation with siRNA suggesting that it occurred independently of EGFR activation (Fig. 6c). Finally, we examined the consequence of IR downregulation with siRNA on HER3 and AKT phosphorylation in the presence of increasing doses of heregulin-1ß. As shown in Fig. 6d, HER3 phosphorylation tended to be reduced while AKT phosphorylation was enhanced and detectable at lower doses of ligand after IR depletion. Altogether, these data indicate that HER3 is in a close proximity to IR in HCC cells and that IR exerts a negative constraint on heregulin-1ßlHER3 that could involve IR-mediated HER3 Y1289 phosphorylation.

\section{Discussion}

Our study shows that HER3 mRNA is upregulated (52\%) in a French collection of 85 HCC compared with adjacent nontumour tissue. In accordance with studies performed on Asian collections of HCC $[19,20]$, we observed that the upregulation of HER3 mRNA was associated to chronic HBV infection. Therefore, it is tempting to speculate that HBV may favour higher HER3 expression during liver carcinogenesis. In this setting, a recent in vitro study showed that the viral protein Hbx transcriptionally upregulates HER3 expression in HCC cells [26]. Moreover, secreted HER3 has been shown to be a biomarker for early $\mathrm{HCC}$ in patients with chronic B hepatitis and cirrhosis [27]. By contrast, it has been recently demonstrated that HCV down-regulates HER3 expression at both transcript and protein levels in the Huh7 cell line [28]. Accordingly, we observed that HER3 mRNA levels were low in HCVrelated HCC. Altogether, these data suggest that the expression of HER3 mRNA is regulated differentially by the viral factors contributing to HCC.

Fold induction for HER3 mRNA expression was also higher in well/moderately differentiated tumours than in poorly differentiated ones. In the same setting, studies conducted on a large panel of hepatoma cell lines showed that HER3 expression was higher in cell lines with an epithelial phenotype than in those with a mesenchymal phenotype [29, 30], suggesting that HER3 is rather a marker of epithelial traits in HCC. 

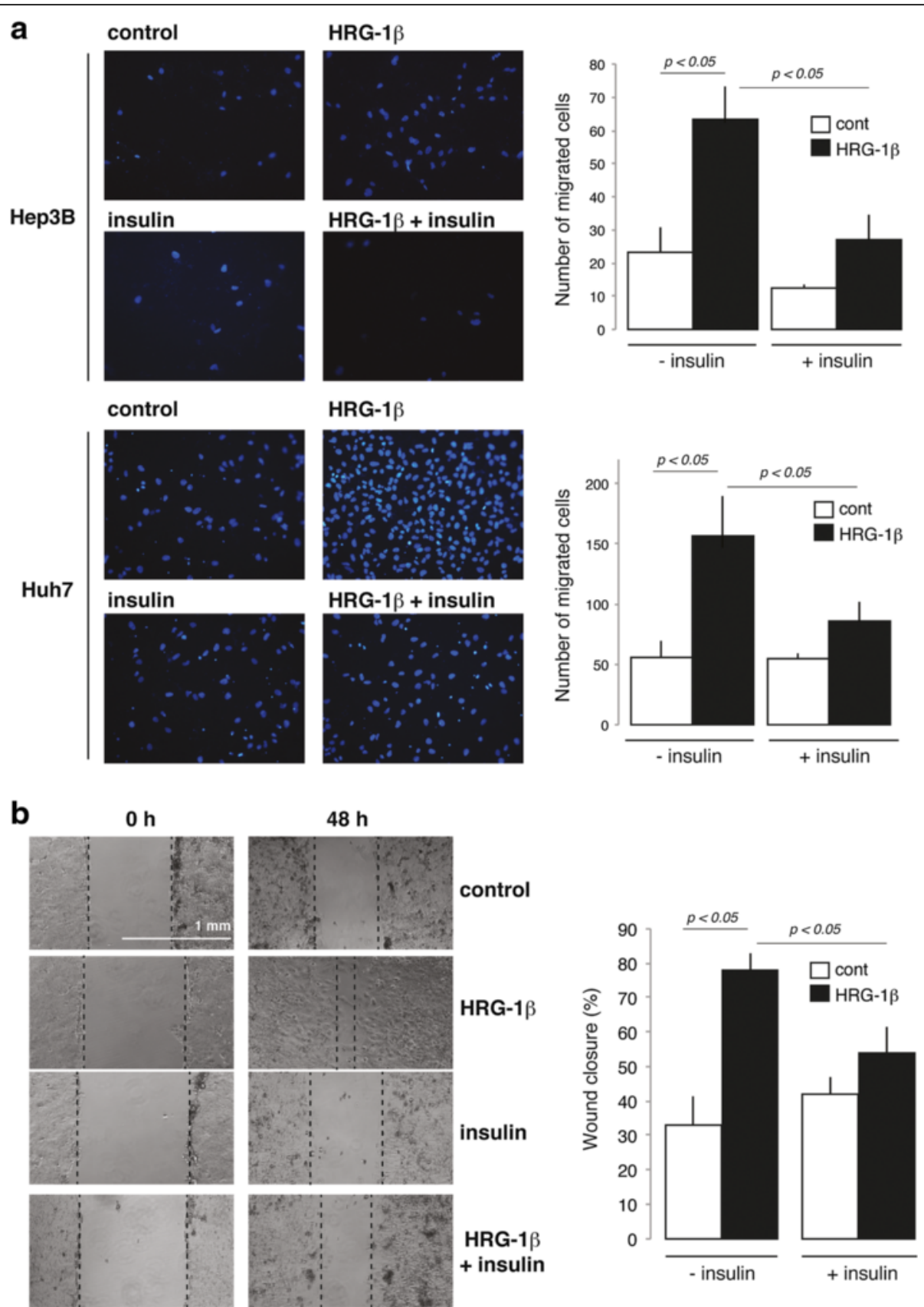

Fig. 4 Effects of insulin on heregulin-1ß stimulation of cell migration in HCC cell lines. a Hep3B and Huh7 cells seeded on Transwell inserts were treated for $24 \mathrm{~h}$ with $10^{-8} \mathrm{M}$ insulin and/or $50 \mathrm{ng} / \mathrm{ml}$ heregulin-1ß (HRG-1ß). Migrated cells were enumerated by microscopy following nucleic acid staining with DAPI. $\mathbf{b}$ Huh7 cells were submitted to a wound-healing assay by scraping cell layer with a p200 pipet tip and were treated for $48 \mathrm{~h}$ with $10^{-8} \mathrm{M}$ insulin and/or $50 \mathrm{ng} / \mathrm{ml}$ heregulin-1ß. The wound closure (\% of H0) was measured

Autocrine expression of heregulin-1ß has been reported to be a predictive biomarker for response to anti-HER3 antibodies, even in tumours showing no significant prognostic association between heregulin-1ß and OS or PFS $[31,32]$. In our HCC collection, the expression of heregulin-1ß transcript was lower in tumours ( $82 \%$ ) than in adjacent tissue, which does not support the existence of heregulin-1ß/HER3 autocrine loops in HCC. Moreover, we have not been able to assign a prognostic value to HER3 and heregulin-1ß mRNA levels. These data contrast with the study by Hsieh and colleagues [20], which reported that upregulation of HER3 mRNA was predictive of early recurrence and poor clinical outcome in a Taiwanese collection of 71 HCC. The reason for such a discrepancy remains unclear. One potential explanation is that the two patient populations diverge in terms of 

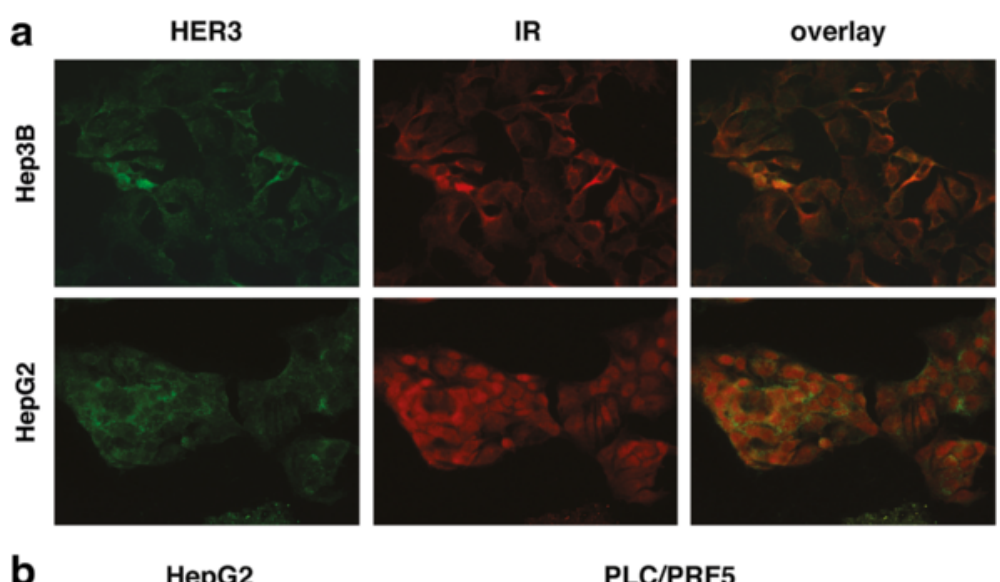

b

HepG2
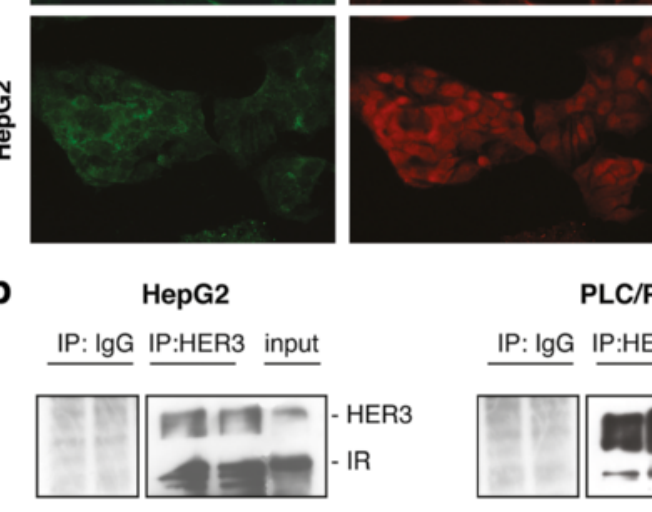

PLC/PRF5

Нер3B
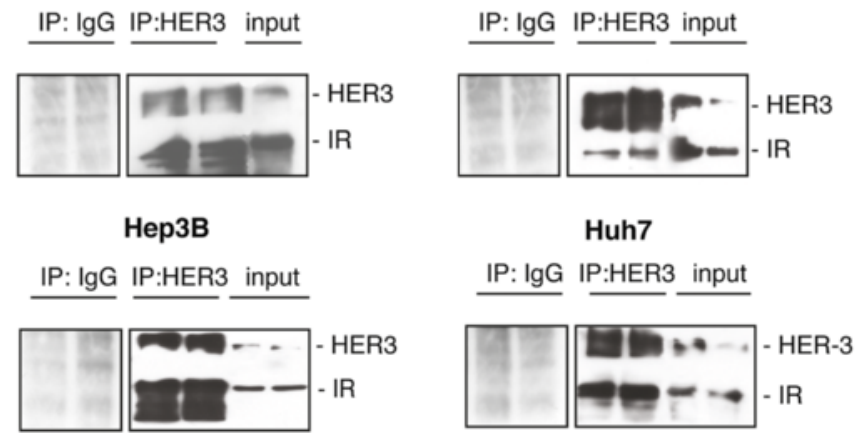

Fig. 5 Association of HER3 to IR in HCC cells. a Hep3B and HepG2 cells were analyzed for HER3 and IR expression by immunofluorescence. b Whole-cell lysates from HCC cells were immunoprecipitated with a HER3 antibody and analyzed by Western blot using an anti-IR antibody. In parallel, negative controls were performed by immunoprecipitating the same lysates with a rabbit lgG. Pictures and blots are representative of two independent experiments

liver-disease etiology. Altogether these data suggest that HCC patients may not derive significant clinical benefit from HER3-directed monotherapies.

There is no standardized method for HER3 detection by immunohistochemistry and information regarding HER3 staining in HCC are limited. The sole extensive study was published with the clone 2F12, which showed frequent HER3 cytoplasmic staining in HCC [18]. In our hands, this clone (and two other ones) did not give signals while the clone RTJ1 yielded cytoplasmic staining but was not reproducible in terms of intensity. The clone RTJ1 has been previously used to detect HER3 in breast $[8,33]$ and lung [34] cancers. However, the reliability of this clone has been challenged by others [35]. An internationally accepted and validated method for immunohistochemistry detection of HER3 needs consideration.

HER3 is a receptor that is finely regulated at the posttranscriptional and post-translational levels in several cell types. Notably, the steady state level of HER3 protein can be regulated by the ubiquitin-proteasome pathway [25]. Since we did not observe correlation between HER3 mRNA and protein levels in human liver tissue, it is highly probable that HER3 is submitted to posttranscriptional and/or post-translational regulation in this tissue. Although insulin is generally considered as an anabolic hormone that supports protein synthesis and inhibits protein degradation, prolonged exposure of cells to insulin also promotes ubiquitin-proteasome degradation of specific proteins such as insulin-receptor substrate-1 [36] and Foxo1 [37]. Liver tumours express IR and insulinemia plays a key role in the pathogenesis of HCC [38]. We show here that insulin promotes the degradation of HER3 protein in untransformed human hepatocytes and that this negative regulation is maintained in some HCC cell lines such as HepG2 and PLC/PRF5 cells. The pathway whereby insulin acts to repress HER3 protein expression involves proteasome engagement. Further studies are needed to examine whether insulin enhances HER3 ubiquitination in HCC cells. In any case, we did not find evidence of a contributory role of NRDP1 in the effect of insulin.

In HCC cells in which insulin did not promote HER3 degradation, we demonstrate that insulin is able to counteract the pro-migratory effect of heregulin- $1 ß$ namely Hep3B and Huh7 cells. The functional interplay between IR and HER3 signalling can be at least partly explained by the physical proximity between the two receptors proved by a coimmunoprecipitation assay. We 


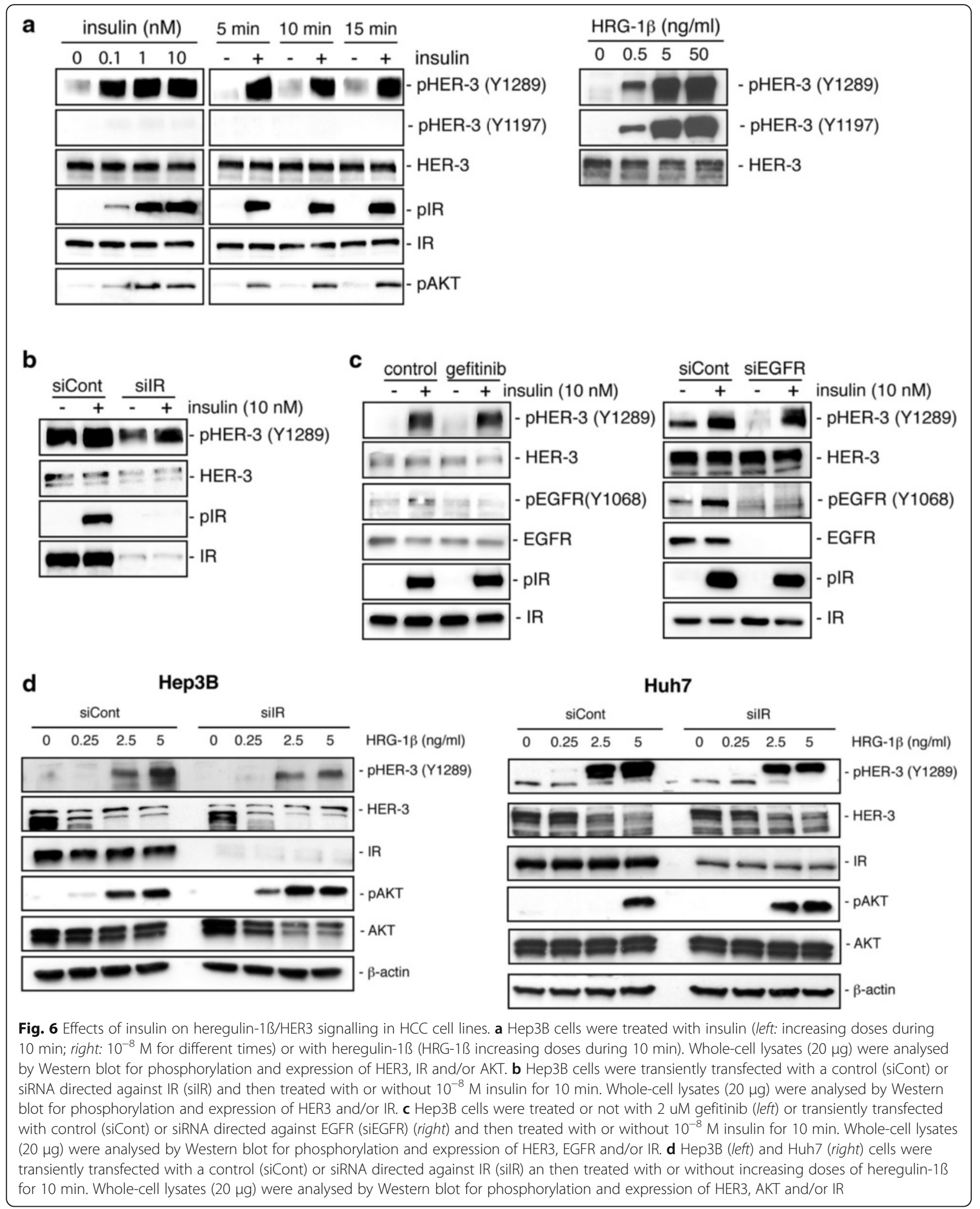


demonstrate that insulin, through its receptor, was able to rapidly phosphorylate HER3. However, the striking observation was that the insulin-induced HER3 phosphorylation was partial, involving Y1289 but not Y1197 residue. Moreover, we report that the depletion of IR protein with siRNA was accompanied by an increase in heregulin-1ß-induced AKT phosphorylation, indicating that HER3 activation was dependent on IR expression levels. The inhibitory effect of IR on heregulin-1ß/HER3 signalling probably explains the ability of insulin to restrict cell migration in response to heregulin-1ß. The underlying mechanisms remain to be deciphered. In particular, it will be of interest to examine the impact of insulin-induced HER3 phosphorylation on heregulin- $1 ß$ affinity and heterodimers balance (EGFR/ HER3, IR/HER3) at the plasma membrane.

\section{Conclusions}

Our study highlights several factors (hepatitis virus, insulinemia) that may regulate HER3 expression in HCC and explain why HER3 expression has no prognostic value in a HCC population, which is heterogeneous in terms of etiology. Further studies are required to bring conclusive answers about the clinical significance of HER3 downregulation and inhibition in the setting of insulin signalling.

\section{Additional files}

Additional file 1: Table S1. Antibodies for Western blot and immunofluorescence. Table S2 Primers used for real-time PCR. (DOCX 78 kb)

Additional file 2: Figure S1. Evaluation of RTJ1 antibody specificity by Western blot. PLC/PRF5 and HepG2 cells were transiently transfected with a control (siCont) or a siRNA directed against HER3 (siHER3). Whole-cell lysates $(20 \mu \mathrm{g})$ were analysed by Western blot for HER3 expression using RTJ1 and 2F12 antibodies. (TIF $338 \mathrm{~kb}$ )

Additional file 3: Figure S2. Prognostic value of heregulin-1ß. KaplanMeier analysis of the probabilities of overall survival (left) and recurrence-free survival (right) according to the upregulation of heregulin-1ß (HRG-1ß) mRNA. Statistical analysis: log-rank test. (TIF $305 \mathrm{~kb}$ )

Additional file 4: Figure S3. Effect of insulin on HER3 and NDPR1 expression. A. HepG2 and PLC/PRF5 cells were treated for $24 \mathrm{~h}$ with $10^{-8} \mathrm{M}$ insulin or IGF-II and analysed for HER3 expression by RT-qPCR. B. HepG2 and PLC/PRF5 cells were treated for 6,17 and $48 \mathrm{~h}$ with $10^{-8}$ $M$ insulin and analysed for NRDP1 expression by RT-qPCR (left). Cells treated for $48 \mathrm{~h}$ with insulin were also analysed for NRDP1 protein expression by Western blot. C. PLC/PRF5 cells were transiently transfected with a control (siCont) or siRNA directed against NRDP1 (siNRDP1) and then treated with or without $10^{-8} \mathrm{M}$ insulin for $10 \mathrm{~min}$. Whole-cell lysates $(20 \mu \mathrm{g})$ were analysed by Western blot for HER3 and NRDP1 expression. $\beta$-actin detection was performed to control protein loading. Values are means \pm SEM of three independent experiments. Blots are representative of two independent experiments. (TIF $489 \mathrm{~kb}$ )

Additional file 5: Figure S4. Effect of heregulin-1 1 on HCC cell proliferation and viability. A. Serum-deprived Hep3B and Huh7 cells were treated with $0.3 \% \mathrm{FBS}, 10 \% \mathrm{FBS}$ or $0.3 \% \mathrm{FBS}$ plus heregulin-1B (HRG-1B, $50 \mathrm{ng} / \mathrm{\mu l})$ and cell number were counted at day 1,2 and 3 . B. Serum-deprived Hep3B and Huh7 cells were treated with $0.3 \% \mathrm{FBS}$, $10 \%$ FBS or $0.3 \%$ FBS plus heregulin-1B (50 $\mathrm{ng} / \mathrm{\mu l}$ ) and cell viability was determined using a MTT assay. (TIF $332 \mathrm{~kb}$ )
Additional file 6: Figure S5. Effects of insulin on HER3 phosphorylation in HCC cell lines. Huh7, HepG2 and PLC/PRF5 cells were treated with insulin (left: increasing doses during $10 \mathrm{~min}$; right: $10^{-8} \mathrm{M}$ for different times). Whole-cell lysates $(20 \mu \mathrm{g})$ were analysed by Western blot for phosphorylation and expression of HER3 and/or IR. (TIFF $1.16 \mathrm{mb}$ )

\section{Abbreviations}

CK19, cytokeratin 19; DAPI, 4',6-diamidino-2-phenylindole; FBS, fetal bovine serum; HBV, hepatitis B virus; HCC, hepatocellular carcinoma; IR, insulin receptor; NT, non tumour; OS, overall survival; RFS, recurrence-free disease; T, tumour

\section{Acknowledgements}

The authors thank tumour biobank HUEP (APHP) for providing human liver tissues, Sylvie Dumont for immunohistochemistry, Claire Calmel for cell line genotyping and Diane Girard for technical assistance and English editing.

\section{Funding}

E. Benabou is a fellow from Ligue Nationale Contre le Cancer; H. Chettouh was a fellow from Ministère de l'Enseignement Supérieur et de la Recherche and Fondation ARC pour la Recherche sur le Cancer; H. Régnault was a fellow from Fondation pour la Recherche Médicale. This work has been supported by grants from INSERM, GEFLUC, Ligue Nationale Contre le Cancer, Cancéropôle lle de France and INCa (INCa-DGOS_5790).

\section{Availability of data and supporting materials section} Not applicable.

\section{Authors'contributions}

Conception and design: CDM. Acquisition of data: $C B, E B, M L, H R$, DW, FM, $H C, L A, F C, O S, O R, L F, C D M$. Analysis and interpretation of data: YC, FP, CDM. Drafting the manuscript: FP, CDM. All authors approved the final version.

Competing interest

The authors declare that they have no competing interests.

\section{Consent for publication}

Not applicable.

\section{Ethics approval and consent to participate}

All patients gave informed consent to the study (molecular characterization of liver tumors obtained after curative resection and study of statistical associations with clinicopathological data). The study was conducted in accordance with the French laws and regulations: liver tissues were obtained from the tumor biobank HUEP (AP-HP) and clinicopathological data were registered at the Commission Nationale de l'Informatique et des libertés (CNIL) under $n^{\circ} 1913901 \vee 0$.

\section{Author details}

'Sorbonne Universités, UPMC Univ Paris 06, INSERM, Saint-Antoine Research Center, 34 rue Crozatier, F-75012 Paris, France. ²Department of Hepatology, AP-HP, Saint-Antoine Hospital, F-75012 Paris, France. ${ }^{3}$ Department of Hepatology, AP-HP, Pitié-Salpétrière Hospital, F-75013 Paris, France. ${ }^{4}$ Department of Pathology, AP-HP, Saint-Antoine Hospital, F-75012 Paris, France. ${ }^{5}$ Histomorphology Platform, UMS 30 Lumic, F-75012 Paris, France. ${ }^{6}$ Human HepCell, Saint-Antoine Hospital, F-75012 Paris, France. ${ }^{7}$ Department of Hepatobiliary Surgery and Liver Transplantation, AP-HP, Pitié-Salpétrière Hospital, F-75013 Paris, France.

Received: 14 June 2016 Accepted: 28 July 2016

Published online: 11 August 2016

\section{References}

1. El-Serag HB. Hepatocellular carcinoma. N Engl J Med. 2011;365:1118-27.

2. Bruix J, Gores GJ, Mazzaferro V. Hepatocellular carcinoma: clinical frontiers and perspectives. Gut. 2014;63:844-55.

3. Llovet JM, Villanueva A, Lachenmayer A, Finn RS. Advances in targeted therapies for hepatocellular carcinoma in the genomic era. Nat Rev Clin Oncol. 2015;12:408-24.

4. Baselga J, Swain SM. Novel anticancer targets: revisiting ERBB2 and discovering ERBB3. Nat Rev Cancer. 2009;9:463-75. 
5. Desbois-Mouthon C. The HER3/ErbB3 receptor: a promising target in cancer drug therapy. Gastroenterol Clin Biol. 2010;34:255-9.

6. Amin DN, Campbell MR, Moasser MM. The role of HER3, the unpretentious member of the HER family, in cancer biology and cancer therapeutics, Semin Cell Dev Biol. 2010;21:944-50.

7. Tanner B, Hasenclever D, Stern K, Schormann W, Bezler M, Hermes M, et al. ErbB-3 predicts survival in ovarian cancer. J Clin Oncol. 2006;24:4317-23.

8. Giltnane JM, Moeder CB, Camp RL, Rimm DL. Quantitative multiplexed analysis of ErbB family coexpression for primary breast cancer prognosis in a large retrospective cohort. Cancer. 2009;115:2400-9.

9. Berghoff AS, Bartsch R, Preusser M, Ricken G, Steger GG, Bago-Horvath Z, et al. Co-overexpression of HER2/HER3 is a predictor of impaired survival in breast cancer patients. Breast. 2014;23:637-43.

10. Reschke M, Mihic-Probst D, Van Der Horst EH, Knyazev P, Wild PJ, Hutterer $M$, et al. HER3 is a determinant for poor prognosis in melanoma. Clin Cancer Res. 2008;14:5188-97.

11. Begnami MD, Fukuda E, Fregnani JH, Nonogaki S, Montagnini AL, Da Costa Jr WL, et al. Prognostic implications of altered human epidermal growth factor receptors (HERs) in gastric carcinomas: HER2 and HER3 are predictors of poor outcome. J Clin Oncol. 2011;29:3030-6.

12. Hayashi M, Inokuchi M, Takagi Y, Yamada H, Kojima K, Kumagai J, et al. High expression of HER3 is associated with a decreased survival in gastric cancer. Clin Cancer Res. 2008;14:7843-9.

13. Wilson TR, Lee DY, Berry L, Shames DS, Settleman J. Neuregulin-1-mediated autocrine signaling underlies sensitivity to HER2 kinase inhibitors in a subset of human cancers. Cancer Cell. 2011;20:158-72.

14. Shames DS, Carbon J, Walter K, Jubb AM, Kozlowski C, Januario T, et al. High heregulin expression is associated with activated HER3 and may define an actionable biomarker in patients with squamous cell carcinomas of the head and neck. PLoS One. 2013:8, e56765.

15. Memon AA, Sorensen BS, Melgard P, Fokdal L, Thykjaer T, Nexo E. Expression of HER3, HER4 and their ligand heregulin-4 is associated with better survival in bladder cancer patients. Br J Cancer. 2004;91:2034-41.

16. Trocme E, Mougiakakos D, Johansson CC, All-Eriksson C, Economou MA, Larsson $\mathrm{O}$, et al. Nuclear HER3 is associated with favorable overall survival in uveal melanoma. Int J Cancer. 2012;130:1120-7.

17. Pan B, Wang R, Huang Y, Garfield D, Zhang J, Chen H. HGF and NRG1 protein expression are not poor prognostic markers in surgically resected lung adenocarcinoma. Onco Targets Ther. 2015;8:1185-91.

18. Ito Y, Takeda T, Sakon M, Tsujimoto M, Higashiyama S, Noda K, et al. Expression and clinical significance of erb-B receptor family in hepatocellular carcinoma. Br J Cancer. 2001;84:1377-83.

19. Neo SY, Leow CK, Vega VB, Long PM, Islam AF, Lai PB, et al. Identification of discriminators of hepatoma by gene expression profiling using a minimal dataset approach. Hepatology. 2004;39:944-53.

20. Hsieh SY, He JR, Hsu CY, Chen WJ, Bera R, Lin KY, et al. Neuregulin/erythroblastic leukemia viral oncogene homolog 3 autocrine loop contributes to invasion and early recurrence of human hepatoma. Hepatology. 2011;53:504-16.

21. Chettouh H, Fartoux L, Aoudjehane L, Wendum D, Claperon A, Chretien Y, et al. Mitogenic insulin receptor-A is overexpressed in human hepatocellular carcinoma due to EGFR-mediated dysregulation of RNA splicing factors. Cancer Res. 2013;73:3974-86.

22. Blivet-Van Eggelpoel MJ, Chettouh H, Fartoux L, Aoudjehane L, Barbu V, Rey $C$, et al. Epidermal growth factor receptor and HER-3 restrict cell response to sorafenib in hepatocellular carcinoma cells. J Hepatol. 2012;57:108-15.

23. Podevin P, Carpentier A, Pene V, Aoudjehane L, Carriere M, Zaidi S, et al. Production of infectious hepatitis $C$ virus in primary cultures of human adult hepatocytes. Gastroenterology. 2010;139:1355-64.

24. Carver RS, Mathew PM, Russell WE. Hepatic expression of ErbB3 is repressed by insulin in a pathway sensitive to PI-3 kinase inhibitors. Endocrinology. 1997;138:5195-201.

25. Mujoo K, Choi BK, Huang Z, Zhang N, An Z. Regulation of ERBB3/HER3 signaling in cancer. Oncotarget. 2014;5:10222-36.

26. Cao K, Gong H, Qiu Z, Wen Q, Zhang B, Tang T, et al. Hepatitis B virus X protein reduces the stability of Nrdp1 to up-regulate ErbB3 in hepatocellular carcinoma cells. Tumour Biol. 2016. doi:10.1007/s13277-016-4936-y.

27. Hsieh SY, He JR, Yu MC, Lee WC, Chen TC, Lo SJ, et al. Secreted ERBB3 isoforms are serum markers for early hepatoma in patients with chronic hepatitis and cirrhosis. J Proteome Res. 2011;10:4715-24.

28. Stindt S, Cebula P, Albrecht U, Keitel V, Schulte Am Esch J, Knoefel WT, et al. Hepatitis $C$ virus activates a neuregulin-driven circuit to modify surface expression of growth factor receptors of the ErbB family. PLoS One. 2016;11, e0148711.

29. Fuchs BC, Fujii T, Dorfman JD, Goodwin JM, Zhu AX, Lanuti M, et al. Epithelial-to-mesenchymal transition and integrin-linked kinase mediate sensitivity to epidermal growth factor receptor inhibition in human hepatoma cells. Cancer Res. 2008;68:2391-9.

30. Zhao H, Desai V, Wang J, Epstein DM, Miglarese M, Buck E. Epithelial-mesenchymal transition predicts sensitivity to the dual IGF-1R/IR inhibitor OSI-906 in hepatocellular carcinoma cell lines. Mol Cancer Ther. 2012;11:503-13.

31. Meetze K, Vincent S, Tyler S, Mazsa EK, Delpero AR, Bottega S, et al. Neuregulin 1 expression is a predictive biomarker for response to AV-203, an ERBB3 inhibitory antibody, in human tumor models. Clin Cancer Res. 2015;21:1106-14.

32. Ocana A, Diez-Gonzalez L, Esparis-Ogando A, Montero JC, Amir E, Pandiella A. Neuregulin expression in solid tumors: Prognostic value and predictive role to anti-HER3 therapies. Oncotarget. 2016. doi:10.18632/oncotarget.8648.

33. Bianchi S, Palli D, Falchetti M, Saieva C, Masala G, Mancini B, et al. ErbBreceptors expression and survival in breast carcinoma: a 15-year follow-up study. J Cell Physiol. 2006;206:702-8.

34. Yi ES, Harclerode D, Gondo M, Stephenson M, Brown RW, Younes M, et al. High c-erbB-3 protein expression is associated with shorter survival in advanced non-small cell lung carcinomas. Mod Pathol. 1997;10:142-8.

35. Anagnostou VK, Welsh AW, Giltnane JM, Siddiqui S, Liceaga C, Gustavson M, et al. Analytic variability in immunohistochemistry biomarker studies. Cancer Epidemiol Biomarkers Prev. 2010;19:982-91.

36. Zhande R, Mitchell JJ, Wu J, Sun XJ. Molecular mechanism of insulin-induced degradation of insulin receptor substrate 1. Mol Cell Biol. 2002;22:1016-26.

37. Matsuzaki H, Daitoku H, Hatta M, Tanaka K, Fukamizu A. Insulin-induced phosphorylation of FKHR (Foxo1) targets to proteasomal degradation. Proc Natl Acad Sci U S A. 2003;100:11285-90.

38. Chettouh H, Lequoy M, Fartoux L, Vigouroux C, Desbois-Mouthon C. Hyperinsulinaemia and insulin signalling in the pathogenesis and the clinical course of hepatocellular carcinoma. Liver Int. 2015;35:2203-17.

\section{Submit your next manuscript to BioMed Central and we will help you at every step:}

- We accept pre-submission inquiries

- Our selector tool helps you to find the most relevant journal

- We provide round the clock customer support

- Convenient online submission

- Thorough peer review

- Inclusion in PubMed and all major indexing services

- Maximum visibility for your research

Submit your manuscript at www.biomedcentral.com/submit
Biomed Central 